
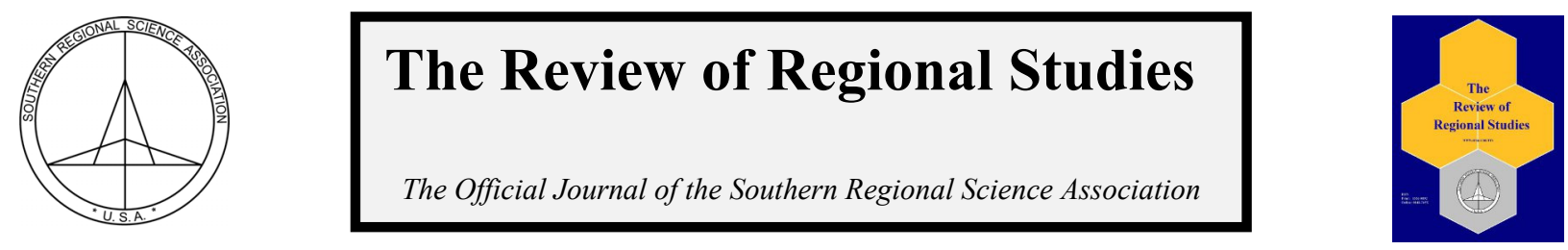

\author{
Fellows Address-Rosslyn, Virginia, April 2, 2016 \\ $55^{\text {th }}$ Meetings of the Southern Regional Science Association
}

\title{
Regional Inequality and Decentralized Governance: Canada's Provinces
}

\author{
M. Rose Olfert \\ Johnson Shoyama Graduate School of Public Policy and Department of Bio-resource Policy, Business and Economics, \\ University of Saskatchewan, Canada
}

\begin{abstract}
Regional scientists commonly concern themselves with topics involving regional inequalities — why they occur and persist, how inequality may be reduced or what exacerbates it, and the impact of policy interventions. Regional inequalities fuel our research and its policy relevance. For most of us, these investigations are in the context of exogenously defined "regions," with political and administrative boundaries originating in a decentralized government context. The regions that are our units of analysis seldom reflect economic realities, yet their boundaries, once drawn, are very persistent and to a large extent determine the degree to which inequalities may be reduced over time, either through private decisions or through government policy. This paper offers a descriptive illustration of fundamental differences among Canada's provinces as a potential constraint on the possibility of convergence over time, interregional migration responses, and the impacts of an explicit national government equalization.
\end{abstract}

Keywords: regional inequality, fiscal federalism, equalization

JEL Codes: R51, R58

\section{INTRODUCTION}

My address about regional inequality and decentralized governance is illustrated with some stylized facts from Canada and its provinces. I believe this topic to be of broad interest to regional economists working in fiscal federations. The political/administrative boundaries and jurisdictions of subnational units in a federation both define the opportunities for, and the constraints on, reducing regional inequalities - a common national policy objective. The scope for interregional migration or explicit "equalization" policies to impact regional differences must be considered within the context of the predetermined boundaries of subnational units. My address is not based on rigorous empirical estimation, but consists rather of simple descriptive statistics and graphs that are suggestive of relationships that are of interest to both academics and policy makers.

I begin with a discussion of the nature of, and reasons for, a decentralized form of government. Canada, like many countries, is a federation of subnational units with some autonomy. It is often considered to be one of the most decentralized federations in the world

Olfert is Perofessor Emerita Johnson Shoyama Graduate School of Public Policy, and Department of Bio-resource Policy, Business and Economics, University of Saskatchewan. E-mail: rose.olfert@usask.ca

(C) Southern Regional Science Association 2016.

ISSN 1553-0892, 0048-749X (online)

www.srsa.org/rrs 
(Bird and Tassonyi, 2003). A number of powers and obligations are devolved from the central government to subnational governments, in Canada's case, the provinces. The provinces that make up Canada today were defined and assembled over a period of more than 80 years. The reasons for their origins and subsequent development were largely political and administrative, sometimes with boundaries drawn quite arbitrarily. The demarcation of provinces was not based on notions of cohesive local economies or functional economic areas. Perhaps not surprisingly, this resulted in a high degree of regional inequality in many respects.

Within a decentralized governance framework, some degree of horizontal equity across subnational units is generally a federal policy objective. Our spatial equilibrium frameworks tell us that migration in the direction of increased expected utility will be an equalizing force. In addition there are explicit government policies in Canada directed at equalization. Canada's equalization payments program is large and has the potential to both influence horizontal equity, as well as introduce incentives that may affect interregional migration.

The question I pose is the following: starting with highly diverse provinces, has the combination of private decisions in response to economic signals and government policy led to convergence among the provinces over time? I do not conduct an analysis that would establish a cause-effect relationship, but rather present some descriptive statistics to examine whether the observed patterns are consistent with theoretical expectations, and raise some questions regarding potential unintended effects.

\section{LITERATURE}

The 1972 "Decentralization Theorem” of Wallace Oates (1972) sets out the advantages of a decentralized form of governance, in terms of subnational governments being more responsive to local conditions and able to perform their functions more efficiently due to lower information costs and better accountability. Where tastes and preferences are not completely homogeneous across the nation, there are benefits to having a decentralized form of governance as local governments can be better attuned to local preferences. Decentralization thus may result in efficiency gains in the provision of public goods and services.

Underlying the decentralization theorem, according to Oates (2005) is the ArrowMusgrave-Samuelson (AMS) perspective of public economics of the 1950s and 1960s. This view is based on two papers that defined the nature of public goods published by Samuelson in 1954 and 1955 (Samuelson, 1954, 1955), Kenneth Arrow's conceptualization of the roles of the public and private sectors (Arrow, 1969), and the view promoted by Musgrave that governments have a role in improving the income distribution and stabilizing the economy through correcting market failures (Musgrave, 1959).

In the AMS framework, governments seek to maximize the social welfare of their constituents, incentivized by electoral pressure in a democracy (Oates, 2005; Vo, 2010). Individual public goods and services, however, vary in the nature of their economies of size as well as in the geographic range over which their benefits are realized. These characteristics imply that different types of public goods can be most efficiently provided by different levels of government. A perfect mapping between the government level and the public good provision would be one where the government jurisdiction coincides perfectly with the area/population over which the public good provides benefits (Oates, 2005). Spillovers of benefits across jurisdictions can be addressed through transfers among governments. 
In a decentralized government framework, individuals will sort themselves into jurisdictions of their choice by a process known as Tiebout (1956) sorting. Subnational units offering different bundles of public goods (and corresponding taxes) will ultimately attract those households whose preferences are reflected in the particular public good bundles. The heterogeneity among subnational units will match the heterogeneous preferences of the citizens in different jurisdictions. Society is better off as a result of the differences in the size and nature of the public sectors in different subnational units.

Decentralization increases efficiency not just because of heterogeneity and accountability, but also because of competition among subnational units (Hamlin, 1991; Qian and Roland, 1998; Winer and Hettich, 2010). The mechanism by which this occurs is again the mobility or potential mobility of the population. Governments are disciplined by the fact that if they operate inefficiently in the provision of public goods and services, individuals will re-locate to more efficient jurisdictions - they "vote with their feet" as in Tiebout sorting. Subnational governments thus have an incentive to operate efficiently to avoid negative net migration of their constituents to other jurisdictions.

While the economic justification for a decentralized government is thus well-established, there are also potential unintended negative side-effects. Vertical and horizontal fiscal imbalances will arise in the first instance because the responsibilities and revenue sources are mismatched between the national and subnational governments, and in the second because subnational units will vary in their tax bases and cost of providing services. Vertical imbalances in the Canadian context originate with the responsibilities and taxing powers as set out in the Constitution of Canada (Bird and Tarasov, 2004; Boadway and Tremblay, 2006). A comprehensive accounting for the incidence of expenditures and revenue capacity will permit the appropriate national-to-subnational transfers to correct for vertical imbalances.

Horizontal imbalances can result in differences in net fiscal benefits (NFB) across subnational jurisdictions that can, in turn, result in inefficient migration known as fiscally-induced migration. Differences in NFB are the result of the quantity and/or quality of public services provided to residents, per tax dollar, being different across subnational units (Boadway and Flatters, 1982a; Vaillancourt and Bird, 2005). Assuming that households include consideration of the public goods' availability and tax cost in their inter-regional migration decisions, differences in NFB can lead to migration that is inefficient in that it does not reflect productivity differences (Boadway and Flatters, 1982a, 1982b; Shah, 1997).

In the public finance literature, Buchanan (1950) first advanced the argument in favor of central government transfers to subnational units for the purpose of equalizing the fiscal capacities of jurisdictions to avoid inefficient labor mobility due to differences in net fiscal benefits (fiscally-induced migration). Unchecked, fiscally-induced migration will lead to a loss in overall social welfare as wealthier jurisdictions will be able to attract migrants with better public services (Buchanan, 1950; Bucovetsky, 1997). Equalization payments from the central government can both achieve greater equity across jurisdictions and correct for the economically inefficient migration that would otherwise occur (Bergvall et al., 2006; Boadway and Flatters, 1982a, 1982b; Bucovetsky, 1997; Flatters, Henderson, and Mieszkowski, 1974; Hercowitz and Pines, 1991; Martinez-Vazquez and Boex, 2001; Mieszkowski and Toder, 1983). Practically, whether equalization payments are warranted depends on whether they are needed to equalize fiscal capacity, whether migration responds to differences in government expenditure (and taxation), and whether the benefits (if any) outweigh the potential unintended side effects.

(c) Southern Regional Science Association 2016. 
In assessing whether differences in revenue capacity leads to differences in net fiscal benefits, the impact on local wages and prices must be considered. It is possible that regional differences in fiscal capacity (often closely related to economic outcomes) may be fully capitalized into wages, rents, and prices, so that there is "nothing to equalize" (Courchene, 2005). Higher revenues in a particular jurisdiction may be matched by higher 'costs of production' of public services. The revenue differences would then not translate into differences in the ability to provide public services, and thus there is no need for equalizing transfers. Courchene (2005) shows that wage levels are positively related to revenues in the Canadian provinces, such that the purchasing power (in terms of public goods provided) of higher revenues in wealthier provinces is reduced. The Canadian equalization program assumes no capitalization, an assumption that is likely unrealistic (Courchene, 2005).

Empirical evidence of the responsiveness of migration to government policy is mixed. In Canada, weak or non-existent effects on interprovincial migration of government policy is reported by Day and Winer (2006), Shaw (1986), and Winer and Gauthier (1982). Mieszkowski and Toder (1983) estimate that the inefficiencies resulting from a fiscally induced out-migration of capital and labor to natural resource endowed states in the United States would be very small. Bakhshi et al. (2009) investigate the influence of equalization payments on interprovincial migration in Canada from 1982 to 2004, controlling for persistent relative attributes of the provinces. They find that, at the margin, federal transfers in the form of equalization payments have virtually no impact on net migration patterns. On the other hand, based on the estimation of a model of Canadian interprovincial migration using 1962-1981 tax data, Day (1992) finds that migration is influenced by provincial government spending, transfers to persons, and average tax rates. Wilson (2003) also shows that migratory flows respond (sluggishly) to changes in equalization payments. Shaw (1986) concurs, finding that social security-type programs offset "natural" incentives to migrate from low income to high-income regions in Canada. There is thus, at best, weak empirical evidence that interprovincial migration in Canada is responsive to either provincial government revenue or expenditure differences.

In the absence of clear evidence that equalization transfers are both needed and effective, this use of public funds requires careful scrutiny. This is especially true in that there may be unintended negative effects of these transfers, namely the creation of a flypaper effect or a welfare trap. The flypaper effect refers to a specific consequence of subnational governments receiving unconditional grants from a central government in a fiscal federalism context. Conceptually, it is relatively straightforward to demonstrate that such grants are likely to be spent rather than being passed on to citizens in the form of tax cuts (Bradford and Oates, 1971; Dahlby, 2011; Gramlich, 1977; Groenewold and Hagger, 2005; Hall, 2008; Hines and Thaler, 1995; Rosen, Wen, and Snodden, 2012; Smart, 1998). Higher subnational government spending resulting from transfers versus if the revenue had been raised locally (i.e., through taxes) suggests that the grants stick where they land rather than being passed on, thus the term "flypaper effect." Overall, there is considerable empirical evidence consistent with the presence of a flypaper effect (Dahlby and Ferede, 2016; Grossman, 1990; Hamilton, 1986; Hines and Thaler, 1995; Inman, 2008; Logan, 1986; Kneebone, 2012; Turnbull, 1998; Winer, 1983).

Empirical investigation of a flypaper effect specifically related to equalization payments in Canada ranges from simple suggestive relationships to rigorous empirical investigations (Courchene, 1970; Crowley and O'Keefe, 2006a, 2006b; Dahlby and Ferede, 2016; Ferede, 2014; Kneebone, 2012; Shah, 1997). If there is no flypaper effect, the proportion of public and

(C) Southern Regional Science Association 2016. 
private goods would not be affected by transfers. Where provincial governments increase spending (purchase of public goods) in greater proportions as a result of receiving federal transfers, a flypaper effect may be suspected.

A second potential negative effect of equalization transfers is the creation of a welfare trap. The receipt of transfers provides an incentive for the subnational government to make decisions to maximize transfer receipts rather than focusing on local long-term growth, creating the potential for a welfare trap. In the long-run, the subnational unit becomes less and less attractive as a place of residence and investment as a result of perverse government behavior (Dahlby, 2002; Glaeser, Kolko, and Saiz, 2001; Polèse and Shearmur, 2006; Myers, 1990). In the regional economics literature, inadvertently interfering with productivity-enhancing migration is a strong argument against policies that target places rather than people. When transfers are attached to places, they create a barrier to mobility - individuals considering migration would be discouraged from doing so because they would not be able to take the benefits of the placespecific subsidy with them (Bolton, 1992; Olfert et al., 2014; Partridge and Rickman, 2008). Impeded mobility may lead to long-term decline for the region where they are "trapped."

In summary, the decentralized governance structure in the Canadian federation offers a range of potential social welfare benefits. However, the empirical evidence of the effectiveness of seeking to correct for the possible unintended negative effects of decentralization is mixed. Questions about the need for, and effectiveness of, equalization payments in terms of their intended effects and potentially negative unintended effects suggest caution and the need for further research.

\section{THE CANADIAN FEDERATION}

Canada currently comprises ten provinces and three territories. At the end of the Seven Year's War in 1763, France ceded its North American territories to Great Britain (Library and Archives Canada, 2009). Following the American War of Independence, which ended in 1783, what remained of British Territory consisted of a number of small colonies, the largest of which was called Canada (later divided into Ontario and Québec). The colonies considered combining in light of their economic problems (access to export markets) and concerns about military protection from incursion by the newly formed United States of America (Library and Archives Canada, 2009). On July 1, 1867, the British North America Act created a four-province Canada, which consisted of Ontario, Québec, New Brunswick and Nova Scotia. Figure 1 shows the original four provinces, where Ontario and Québec consisted of much smaller geographic areas than they now do.

Over the next 80 years, the other six provinces joined for a variety of reasons ranging from a threat from the Métis (Manitoba), the gold rush (British Columbia), the development of new industries such as agriculture (Alberta and Saskatchewan), and the subsequent need for education and other public services (Alberta and Saskatchewan). In most cases, economic and debt difficulties, and in some cases concern about potential annexation by the United States, played a role (Library and Archives Canada, 2009). The last province to join Canada was Newfoundland in 1949. Table 1 shows the timeline through which the ten provinces joined to form what is now Canada. Figure 2 shows the map of the current provinces and territories. In this paper we focus on the ten provinces because the arrangements between the central government and the territories is fundamentally different. 
Figure 1: Canada's Original Four Provinces 1867

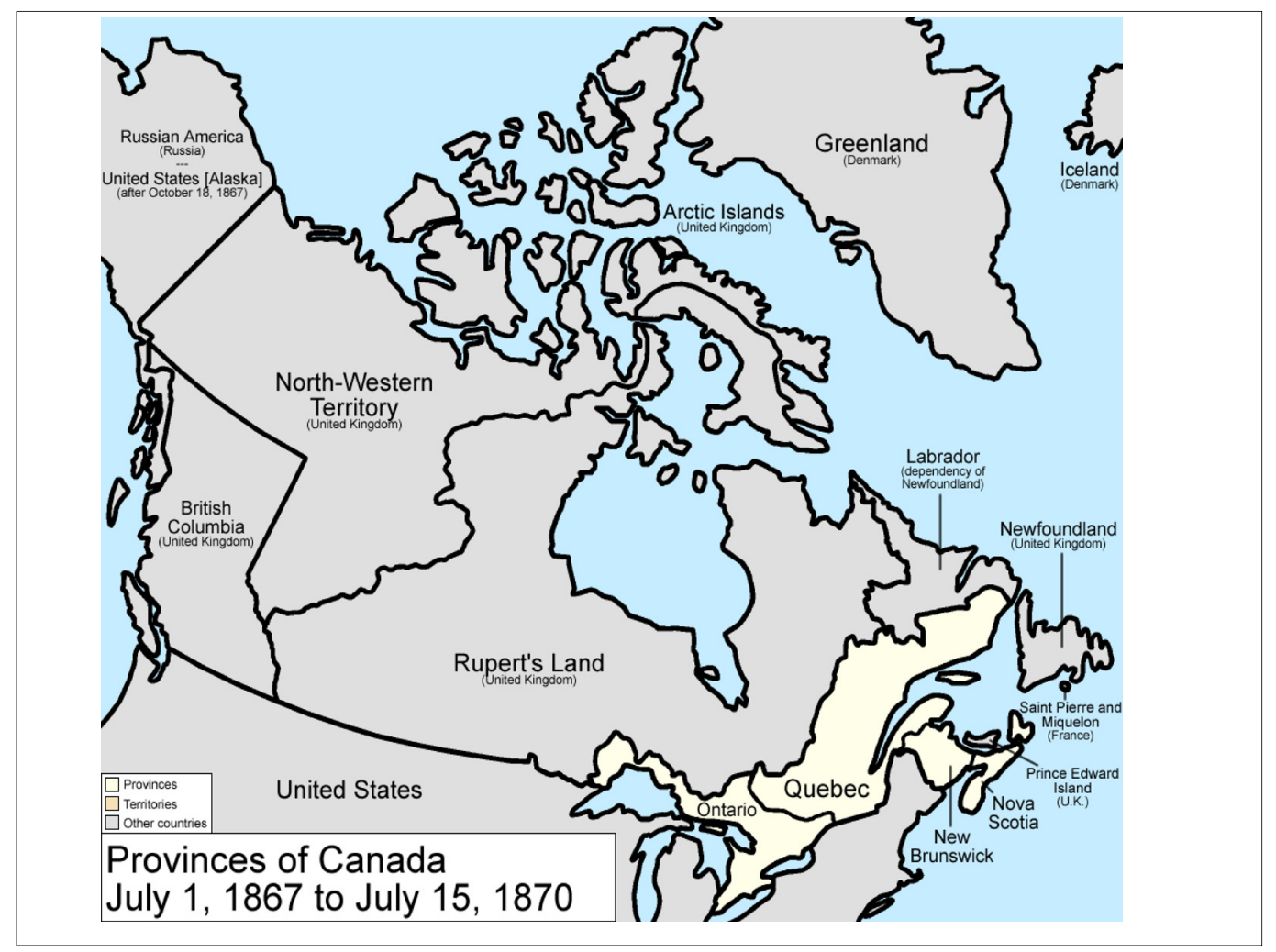

Source: https://commons.wikimedia.org/w/index.php?curid=575707

Table 1: Building the Canadian Federation, Ten Provinces

\begin{tabular}{|l|l|}
\hline Date of Joining Canada & Province \\
\hline July 1,1867 & Ontario \\
& Québec \\
& Nova Scotia \\
& New Brunswick \\
\hline July 15,1870 & Manitoba \\
\hline July 20,1871 & British Columbia \\
\hline July 1,1873 & Prince Edward Island \\
\hline September 1,1905 & $\begin{array}{l}\text { Alberta } \\
\text { Saskatchewan }\end{array}$ \\
\hline March 31,1949 & Newfoundland \\
\hline
\end{tabular}

Several provinces (as illustrated by Québec and Ontario in Figure 1) were initially of a different size and shape than is currently the case. Their expansions to current size reflected the need to assign all the area of the former British territories to some province or territory within Canada. Lines of latitude and longitude as well as rivers and lakes were sometimes used as convenient boundaries for the provinces.

(c) Southern Regional Science Association 2016. 
Figure 2: Provinces and Territories of Canada, 2016

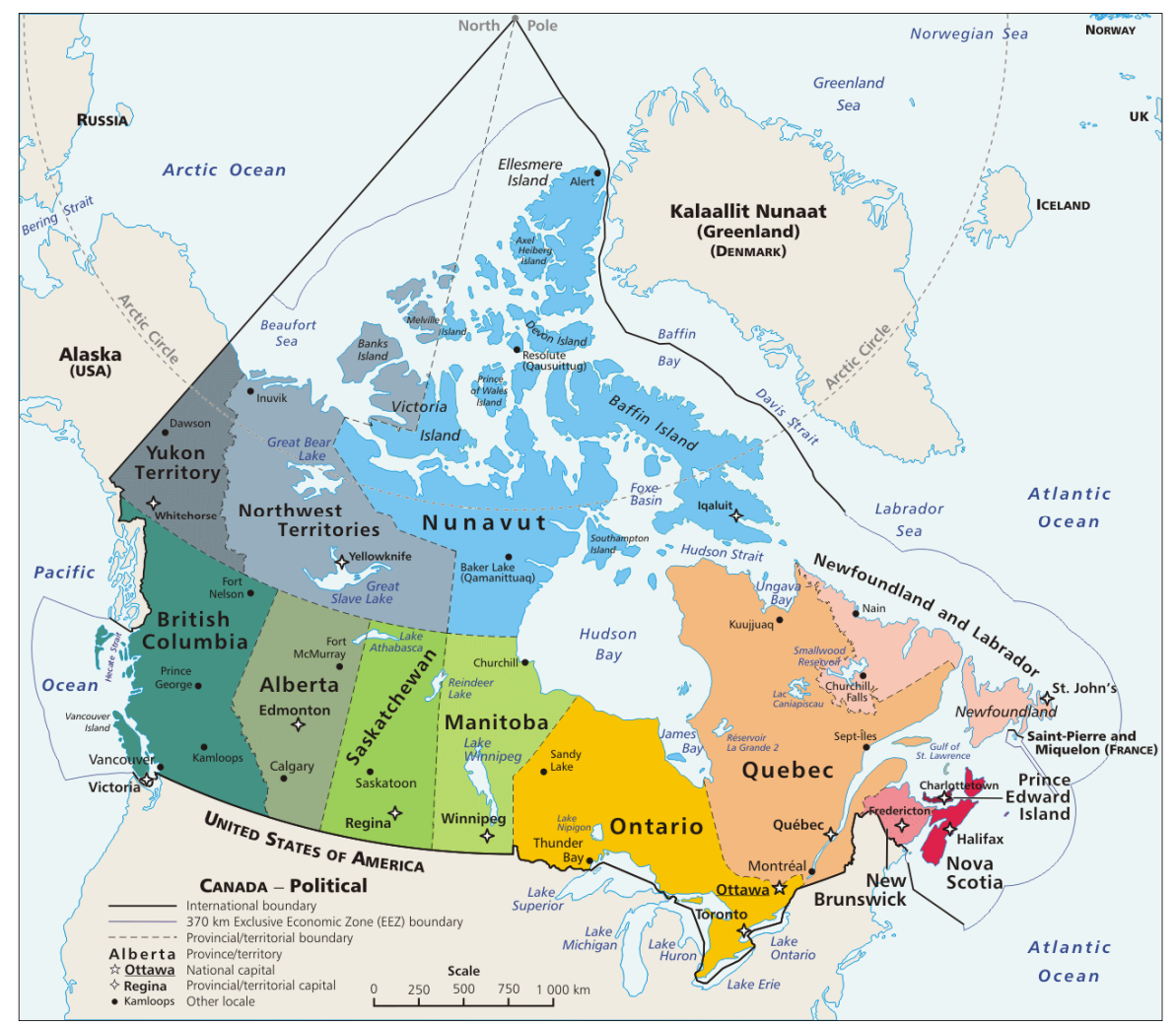

Source: Canada Provinces and Territories Map, available at: http://mapsof.net/canada/canada-provinces-and-territories-map

The provinces as they are currently vary in size from 2,185 square miles in the case of Prince Edward Island (0.1 percent of the total area of Canada) to 595,391 square miles for Québec (15 percent of Canada). Though Canada's land mass is huge, the population in each of the provinces is primarily strung along a narrow band along Canada's southern border. The economic structure and health of the provinces is largely a result of their natural resource bases, economic geography, and their maturity in the Canadian federation. Central Canada (Ontario and Québec), with the nation's capital, a focus of early settlement, and access to navigable waters (historically important), had a head start in terms of attracting population and businesses, especially head offices of financial and business service firms. This path dependency has had persistent consequences. The greater Toronto area has a population of over six million, about 17 percent of Canada's population.

The historical formation of Canada's provinces suggests little role for the consideration of cohesive economic regions. There were clearly major inequities among provinces from the beginning. Yet the Canadian government has, also from the beginning, as set out in the British North America Act and later in the Canadian constitution, been concerned with reducing the inequalities among the provinces. 


\section{Figure 3: Canada's Population Proportions by Province, 1951}

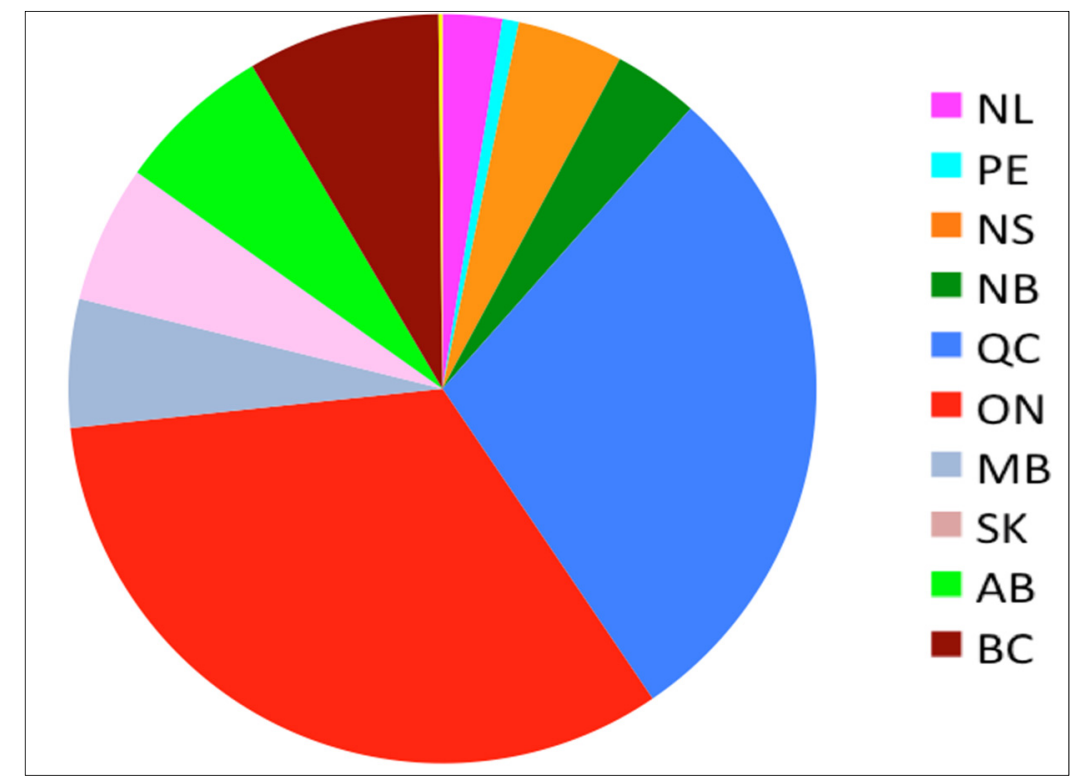

Source: Statistics Canada. Table 051-0001, Estimates of population, Canada, provinces and territories, annual.

\section{POPULATION AND ECONOMIC STRUCTURE OF THE PROVINCES}

The distribution of Canada's population over the provinces and territories in 1951, the first Census following the inclusion of Newfoundland, is show in Figure 3. Newfoundland (NL) is shown at the 12:00 o'clock position in bright fuchsia pink and the rest of the provinces from east to west follow in sequence. Québec (QC), in royal blue, and Ontario $(\mathrm{ON})$, in red, each comprised close to one-third of Canada's population. At the other extreme, Prince Edward Island (PE), in turquoise blue just after NL, with less than 100,000 population, made up only 0.7 percent. Saskatchewan (SK), the thin pink wedge at about 10:00 o'clock represented about 6 percent of the population, about the same as each of the other two prairie provinces of Manitoba $(\mathrm{MB})$, in gray, and Alberta $(\mathrm{AB})$, in the neon green. The very thin sliver of yellow is the combination of the territories.

The population distribution of the provinces is in part a reflection of their economic bases and the evolution of their industries over time. Figures 4 and 5 show the current relative important of selected industries in provincial gross domestic product (GDP). While the historical distribution would be more pertinent, the current distribution is nevertheless basically reflective of what would have been the case in 1951, at least in terms of the distinction between primary and other sectors of the economy. The importance of primary production to the economies of $\mathrm{NL}, \mathrm{AB}$, and SK is clear in Figure 4. Mining/oil and gas and agriculture/forestry/fishing are shown separately in Figure 4, though it is really primary sector dependence (combined) that is the most important. Primary production comprises more than 25 percent of GDP of these three provinces, leaving them very vulnerable to commodity price fluctuations. In the large and central provinces of $\mathrm{ON}$ and $\mathrm{QC}$, primary production makes up less than 3 percent of their provincial economies. 


\section{Figure 4: Percentage Distribution of GDP by Industry, Agriculture-Forestry-Fishing and Mining-Oil and Gas, NAICS, 2013}

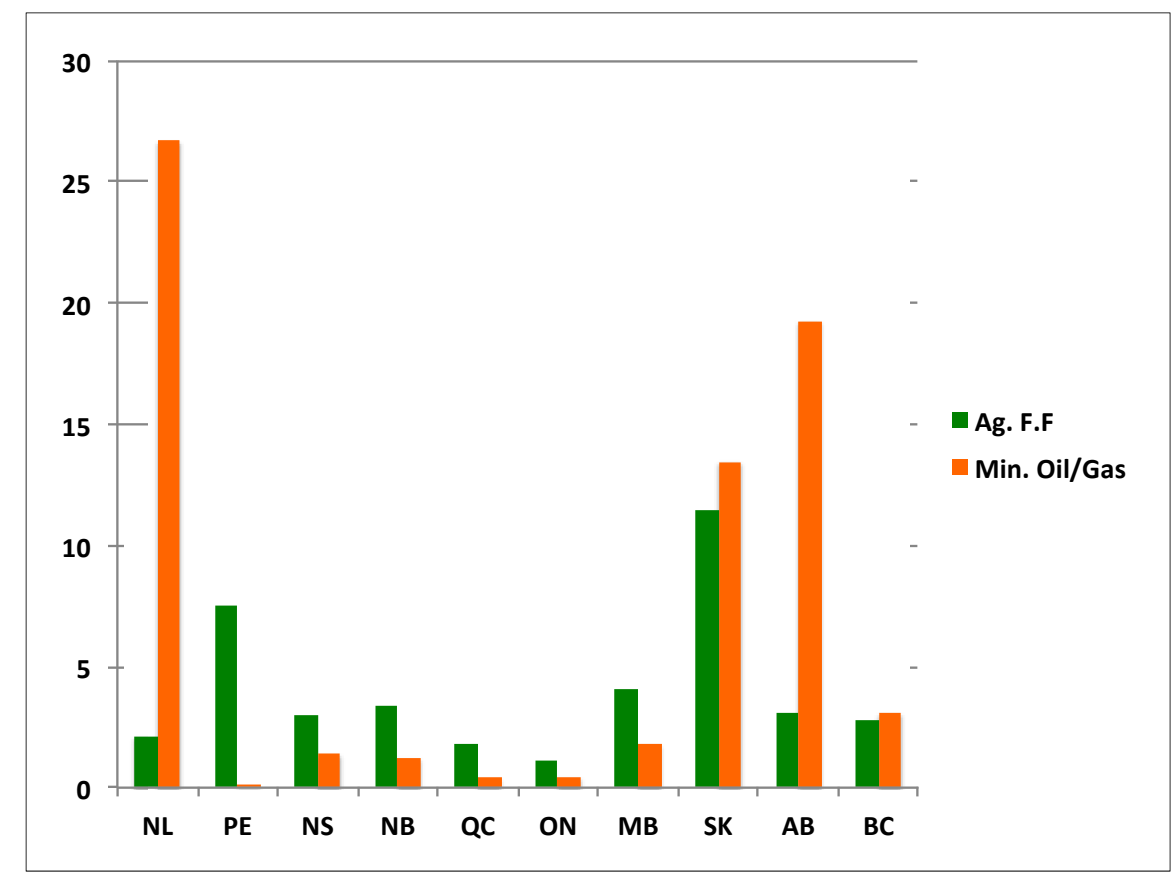

Source: Statistics Canada, Cansim Table 379-0025

Figure 5 illustrates the relative importance of manufacturing, scientific, and professional services in the provinces. Manufacturing comprises 15 percent or more of the provincial GDP in $\mathrm{ON}$ and QC. When manufacturing is considered together with professional and scientific industries, the combination accounts for more than 25 percent of these economies. In SK and $\mathrm{NL}$, on the other hand, manufacturing is relatively absent and professional/scientific industries comprise about 6 percent, reflecting the remoteness of these provinces, and the absence of large (500,000 population) urban centers. Both manufacturing and professional/scientific industries are somewhat more developed in $\mathrm{AB}$, the other primary sector dependent province, making up close to 20 percent of its economy. $\mathrm{AB}$ has two urban centers of more than 1 million people, likely accounting for some measure of diversification.

Another look at economic differences across provinces can be seen in Figure 6, a line graph showing GDP per capita by province over the past 35 years or so, indexed to the ten province average. There are a number of stories here, but I would like to draw your attention first to the range. At the bottom, in turquoise blue, we have PE hovering at about 60 to 70 percent of the national average, while at the top is $\mathrm{AB}$, in neon green, persistently at least 50 percent above the national average. Saskatchewan (in pink) is mostly above the national average by about 10 percent. Of course ON (in red) is very close to the national average because it so strongly influences the average because of its size. QC (in royal blue), although also a large province, is consistently close to 20 percent below the national average. NL has experienced the most dramatic change over time, with per capita GDP less than 80 percent of the national average until about 2000 and then increasing to as much as 20 percent above the average. Most provinces have remained remarkably stable in their relative position.

(C) Southern Regional Science Association 2016. 
Figure 5: Percentage Distribution of GDP by Industry, Manufacturing, Professional/Scientific, NAICS, 2013

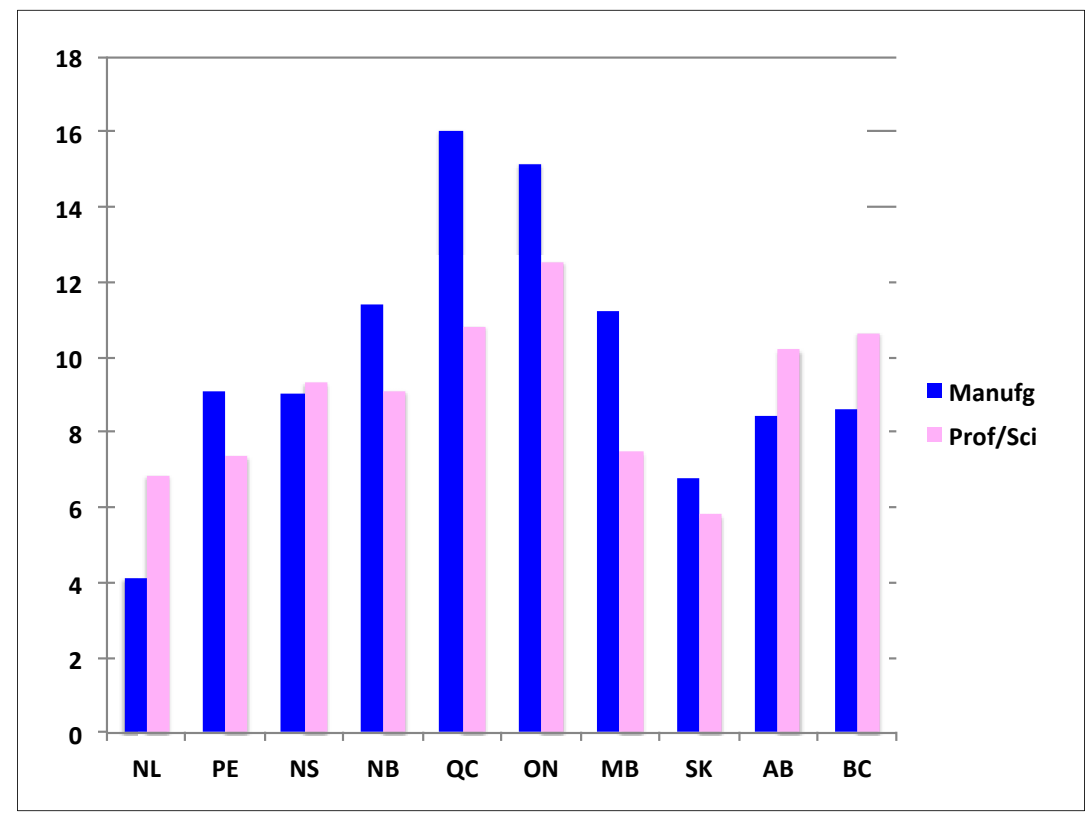

Source: Source: Statistics Canada, Cansim Table 379-0025

In summary, the provinces are very heterogeneous in geographic and population size, their economic bases, their remoteness from major markets, and their productivity. There are both persistent differences among the provinces and some changes in their relative position over time due to cyclical influences.

Figure 6: GDP per Capita by Province, Indexed to Canada

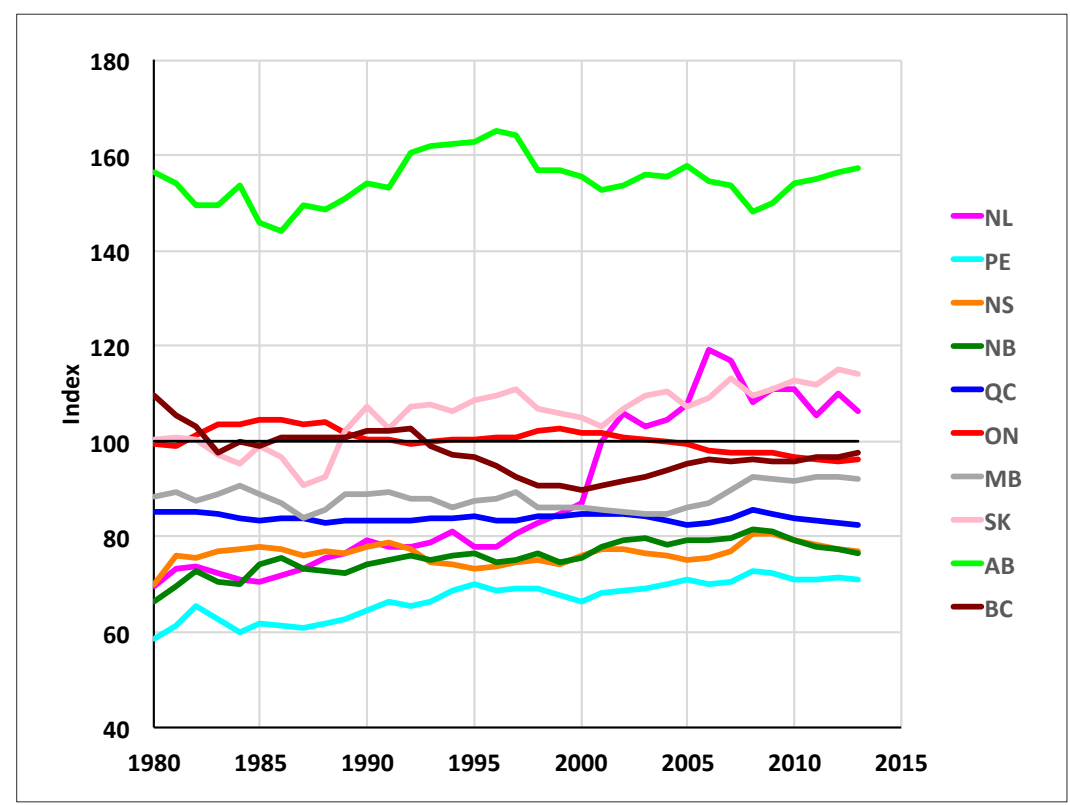

Source: Statistics Canada, Cansim Table 384-0038.

(C) Southern Regional Science Association 2016. 
For purposes of comparing a number of indicators in the following sections, I am going to label five provinces as high-income provinces based on their 2015 relative per capita GDP position, and five as "Low Income," from Figure 6. This rather crude division, puts ON (red), $\mathrm{BC}$ (brown) and $\mathrm{AB}$ (neon green) in the high-income group, but also SK (pink) and NL (turquoise blue) though these latter two provinces have gained this status only very recently and maybe only temporarily due to the high oil prices that prevailed until the fall of 2014 . That leaves five provinces as low-income provinces - the three Atlantic provinces of NS, NB and PE, plus QC and MB.

\section{NET INTERPROVINCIAL MIGRATION}

I turn first to net interprovincial migration in these two groups of provinces. Migration in response to differences in expected utility will play an important role is convergence over time among the provinces. As a first approximation, and recognizing that amenities will also play a role in migration decisions, I look at GDP per capita as an indicator of economic conditions that may influence migration. We would expect the high-income provinces to be the net recipients of interprovincial migration to the extent that migration is a response to economic conditions and that there are minimal differences in amenities (Partridge et al., 2007). Indeed, as shown in Figure 7, $\mathrm{AB}$ (neon green), $\mathrm{ON}$ (red) and $\mathrm{BC}$ (brown) have had mostly positive net migration, with some variations over time. NL (turquoise) has had mostly negative net migration corresponding to its years with below average GDP per capita before 2000, though that moderated during the recent oil development in that province. SK (in pink), like NL, has historically had mostly negative net migration and only recently seen some positive, short-lived positive net migration.

Among the group of low-income provinces (Figure 8), we do see mostly negative net migration as expected, with varying degrees of cyclical fluctuations. QC (in royal blue) is the only province showing negative net migration in every year.

Figure 7: Net Migration Rate, High-income Provinces, 1980-2015

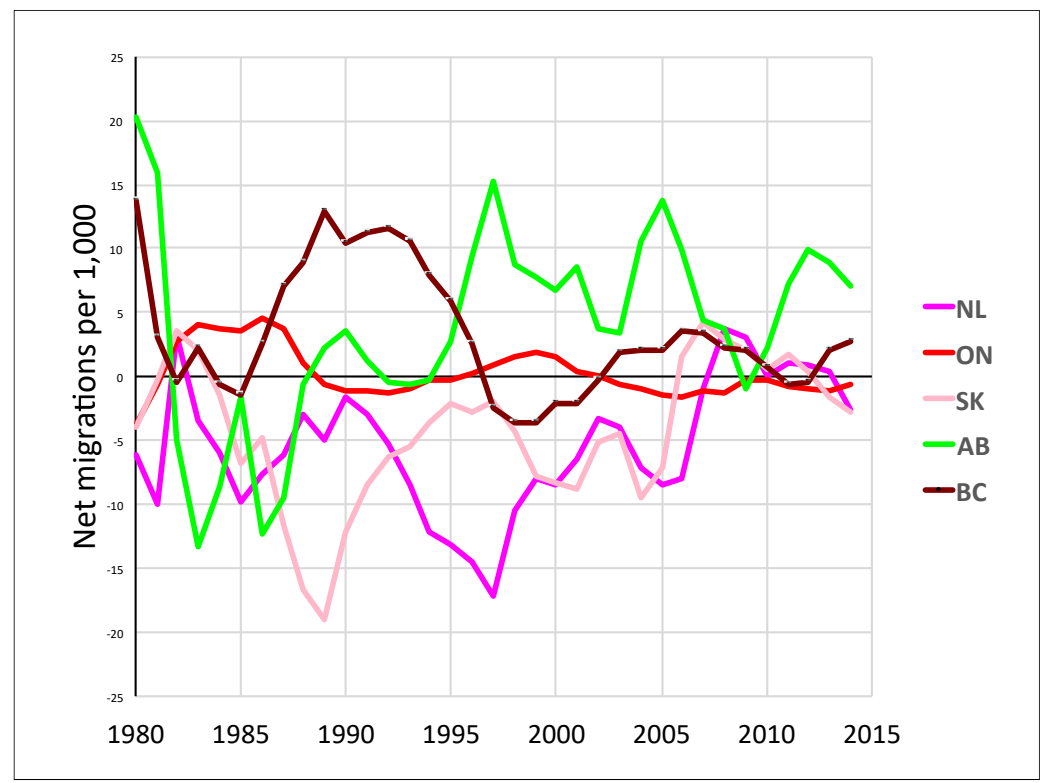

Source: Statistics Canada, Cansim Table 051-0004, Components of population growth.

(C) Southern Regional Science Association 2016. 
Figure 8: Net Migration Rate, Low-income Provinces, 1980-2015

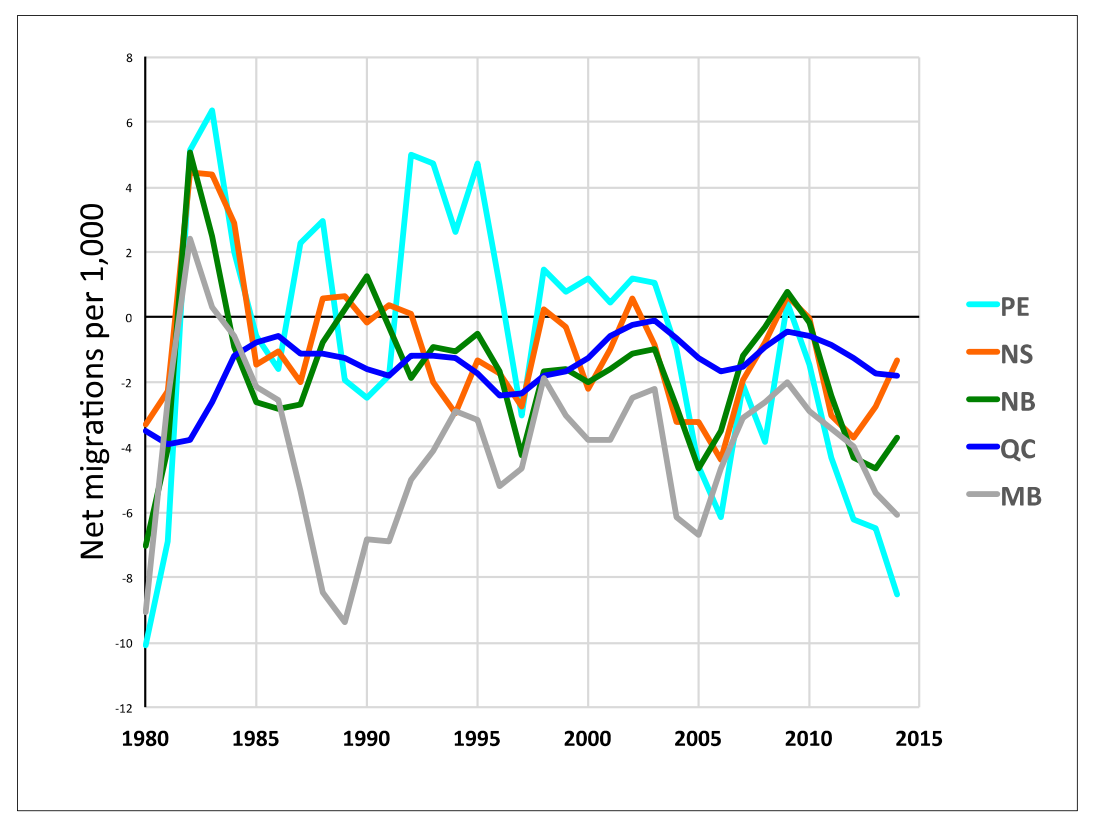

Source: Statistics Canada, Cansim Table 051-0004, Components of population growth.

In summary, although there is large cyclical variation, the high-income provinces of ON, $\mathrm{AB}$, and $\mathrm{BC}$ have had mostly positive net migration. NL and SK only recently, thanks to oil prices, switched from chronic negative to zero or (weak) positive net migration. Low Income provinces have had mostly negative net migration as expected.

Returning to the population pie chart from Figure 3, and adding 2015, we see the net results of the net migration over time, comparing 1951 and 2015, in Figure 9. ON (red), AB (neon green), and BC (brown) have grown at the expense of the other provinces. Ontario with about $1 / 3$ of the Canadian population in 1951 now has 40 percent. QC (royal blue) also starting with close to $1 / 3$ has shrunk to about 25 percent of the population. Over that period, SK (pink) shrank from 6 percent to 3 percent because it remained of relatively constant size while the rest of Canada grew, due to persistent negative net migration. While these changes in population proportions reflect the net result of interprovincial net migration, for the largest provinces international migration will also play a role.

\section{GOVERNMENT POLICY}

Canada has, enshrined in its Constitution, a commitment to providing equalization transfers from the central government to poorer provinces to ensure, as it is written in Section 36(2) of the constitution, "reasonably comparable" provincial government revenues so that the provinces can provide "reasonably comparable" public services (Constitution Act, 1986). The equalization transfer flows are the result of the calculation of per capita equalization entitlements based on each province's per capita government revenue capacity (tax base) compared with the national average. There is an underlying equalization formula for the determination of the entitlements (Roy-César, 2008), though there have been frequent and substantial over-rides and ad hoc adjustments, primarily in response to federal government budgetary constraints and negotiated special treatments. 
Figure 9: Canada's Population Proportions by Province, 1951 and 2015

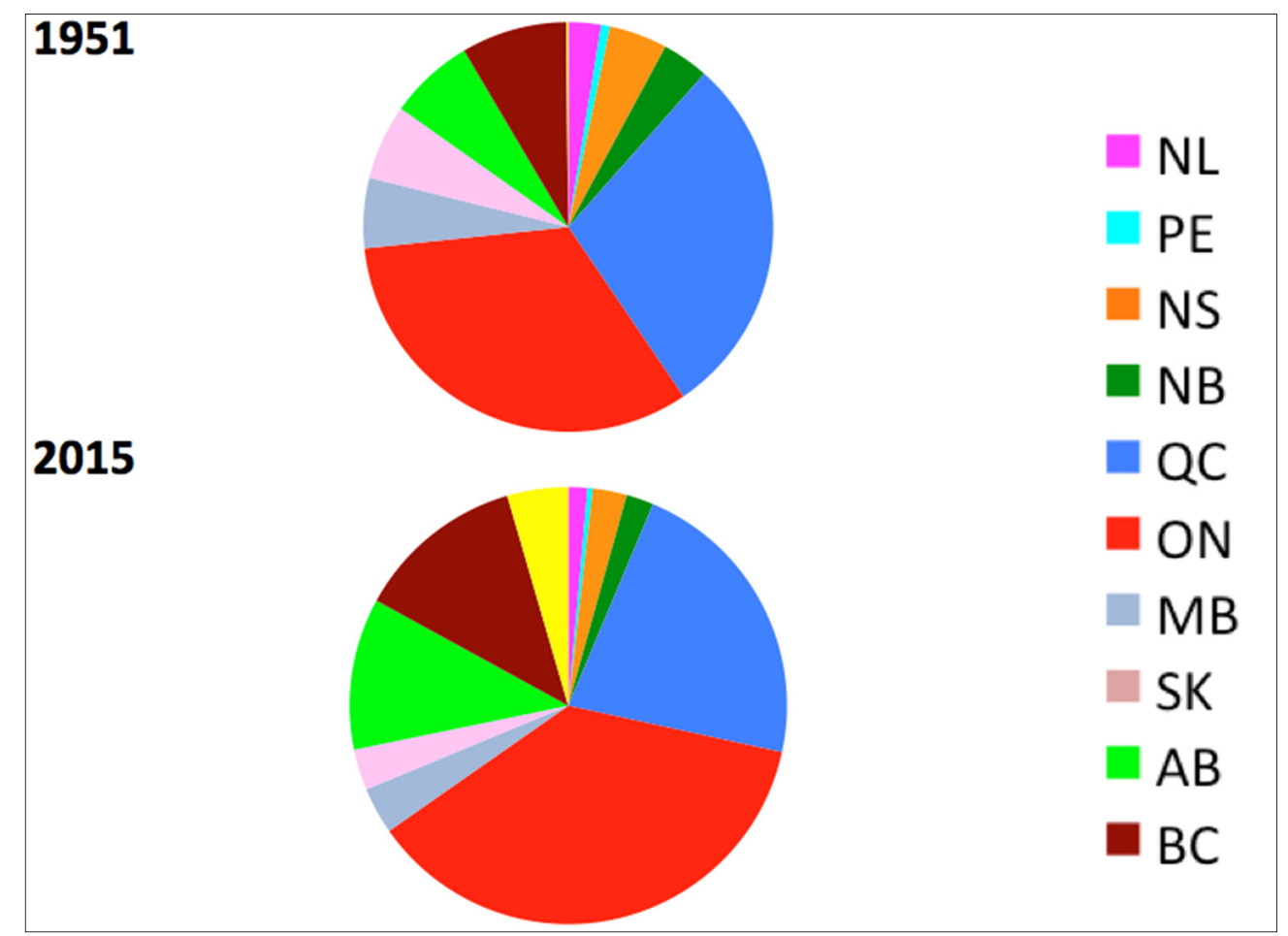

Source: Statistics Canada. Table 051-0001, Estimates of population, Canada, provinces and territories, annual.

Figure 10 shows the distribution of total equalization transfers among the provinces at two points in time. QC (royal blue) has always received more than 50 percent of the total transfers. $\mathrm{AB}$ has never received equalization transfers (no neon green). Until 2009 that was also true for ON (red), and indeed Ontario's appearance as a recipient province in 2009 was of grave concern to the federal government, mostly because of the size of ON. SK was a recipient in 1980, represented by the pale pink sliver close to 12 o'clock, but not a recipient in 2015; NL (fuchsia pink) received a significant share in 1980, but none in 2015. Provinces exiting and entering recipient status is as expected in response to changes in the economic fortunes of the provinces relative to the nation as a whole, along with the impact on government revenues. Some provinces, however, have remained long-term recipients, namely the three Atlantic provinces plus QC and MB.

A second view of the size of equalization payments going to the provinces is in per capita terms, shown in Figure 11. The size of these transfers is significant for some provinces, up to $\$ 2,000$ per capita for PE and NL, in turquoise blue and fuchsia pink respectively. ON (red) and $\mathrm{BC}$ (brown) have received very low and inconsistent amounts, but ON's large population makes even small per capita payment potentially significant. QC (in royal blue), though it accounts for over half of total equalization transfers, in per capita terms is relatively low ranging from $\$ 750$ to $\$ 1,000$ per capita.

(C) Southern Regional Science Association 2016. 
Figure 10: Distribution of Equalization Payments by Province, 1980 and 2015

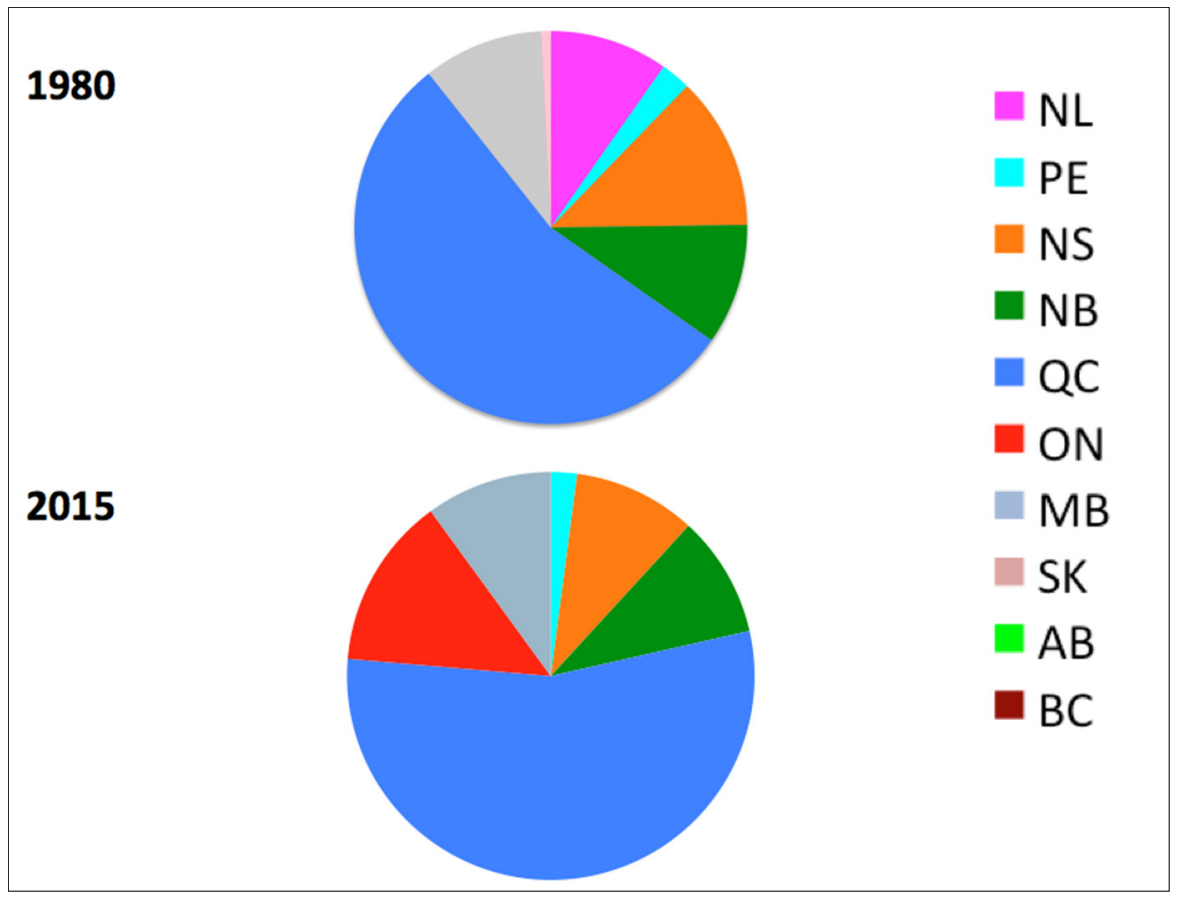

Source: Canada, Department of Finance.

Figure 11: Equalization Payments Per Capita to Provinces, 2007 Dollars, 1980-2015

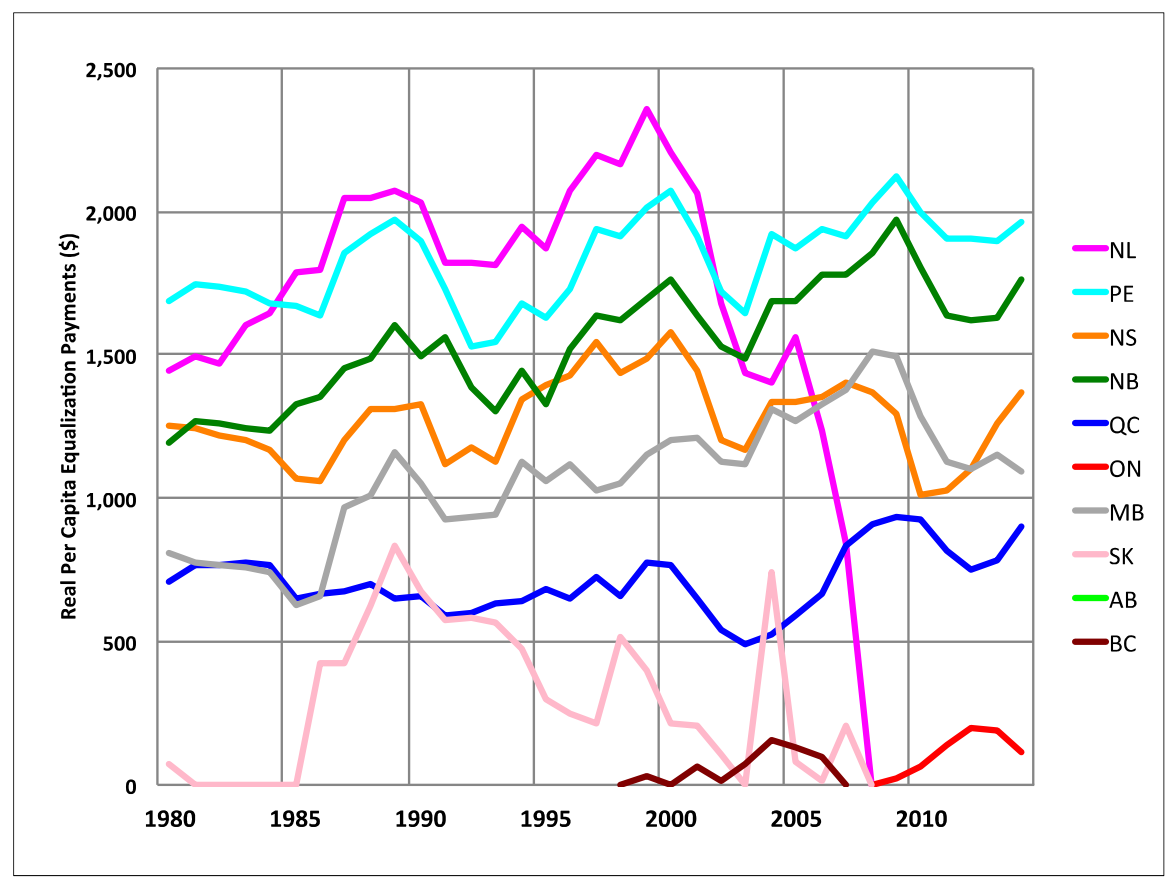

Source: Canada, Dept. of Finance; Statistics Canada, Cansim Table 051-0001 Estimates of Population

(C) Southern Regional Science Association 2016. 


\section{Figure 12: Equalization Transfers as a Share of Provincial Revenues, 1981-2014}

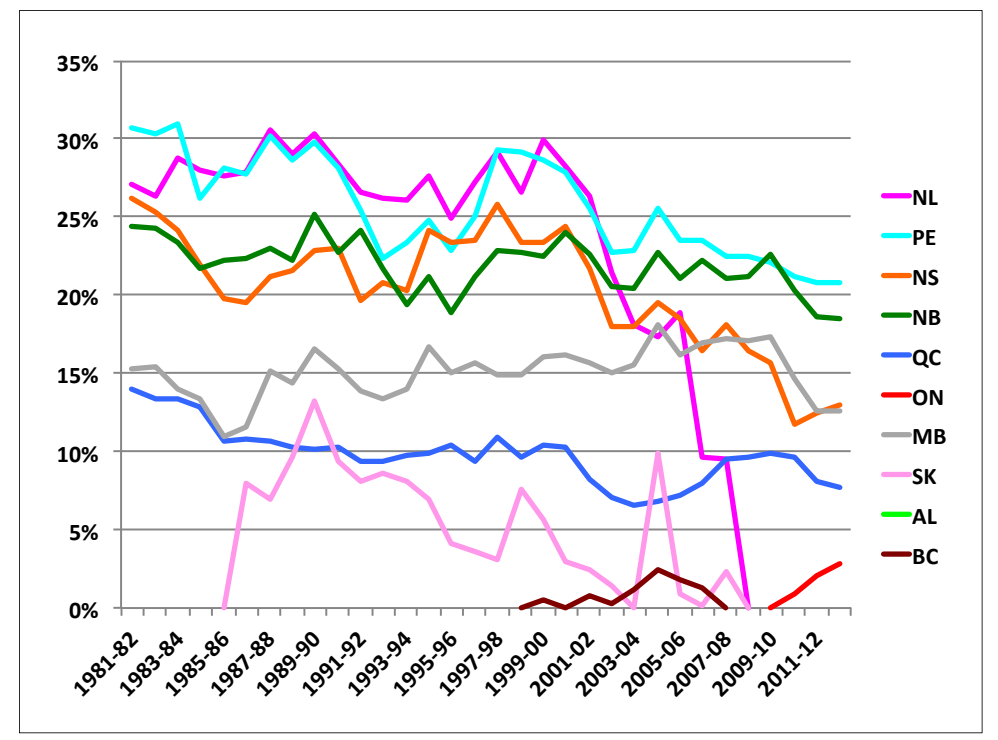

Source: Canada, Department of Finance; Statistics Canada, 1981-88, Cansim Table 384-0004; 1989-2009, Cansim Table 385-0002; 2007-2013, Cansim Table 385-0034

A third way of considering the size and importance of equalization payments is their size relative to total provincial government revenues, shown in Figure 12. We see equalization transfers ranging up to 30 percent of revenues, again for the Atlantic provinces, the four top lines, except that NL drops off after about 2005 due to oil revenues. For the province of QC, receiving about half of the total amount of equalization transfers overall, these transfers make up as much as 14 percent of total revenues, and more recently falling to about 7 percent. Clearly, equalization transfers are much coveted by recipient provincial governments, and changes to the formula are hotly contested. Even 10-15 percent is a very significant portion of provincial government budgets.

As indicated in the literature reviewed above, one of the concerns that arises regarding unconditional transfers from a central government to subnational units is the possibility of a flypaper effect. To isolate these effects, one may look simply at per capita government expenditures relative to the national average as a first approximation. While an imperfect proxy, patterns in per capita expenditures may indicate whether expenditure patterns are consistent with a flypaper effect. In examining these patterns, I have grouped the provinces once again into the High and Low Income provinces, based on their 2015 relative position in terms of GDP per capita. The ex ante expectation would be that relatively high-income provinces would have the ability to offer more services, and thus might have relatively high per capita expenditures. Low Income provinces may not have the capacity to provide services (the underlying rationale for the existence of the equalization program), thus we might expect that their per capita spending would be relatively low. A reversal of this pattern may suggest that the investigation of a potential flypaper effect is warranted.

Provincial per capita total government spending for the high-income provinces is shown in Figure 13. We see that $\mathrm{ON}$ (red) has consistently had per capita government expenditures below the national average, and this is also mostly the case for $\mathrm{BC}$ (brown). AB (in neon green), though also a high-income province, has had a varied experience, though none of this can be 
attributed to equalization transfers since $\mathrm{AB}$ has never been a recipient. Spending windfall gains due to high oil prices, and the effect on local wages and rents, are more likely explanations here. The latter could also explain the relatively high per capita expenditures in SK and NL in very recent years, though their per capita expenditures were also high in their low income years.

Turning to the low-income provinces in Figure 14, all of which have consistently received equalization payments in every year, all except NS have per capita government expenditures above the 10-province average. This raises the question of whether these high expenditures may be related to the receipt of transfers, that is, the presence of a flypaper effect. There are, however, a number of other factors that may explain relative provincial per capita spending, especially scale considerations in the provision of public services. These simple descriptive statistics are, however, consistent with such an effect.

\section{CONVERGENCE}

Returning to the question I began with, has there been convergence among the provinces as would be expected as a result of interprovincial migration, and as is intended by government policy directed at equalizing public services across provinces? Given the vast initial (and persistent) differences in the sizes and economic conditions of the ten provinces, it may seem optimistic to expect convergence to occur. There are, of course, various ways of viewing and measuring convergence, and very sophisticated techniques to do so. Disentangling the component influences in the net effects is indeed a complex matter. I am going to use here a simple descriptive statistic to proxy economic conditions, namely household disposable income

\section{Figure 13: Provincial Government Per Capita Spending, Indexed to the Ten Province Total, (Recent) Non-Equalization-Recipients, 1980-2013}

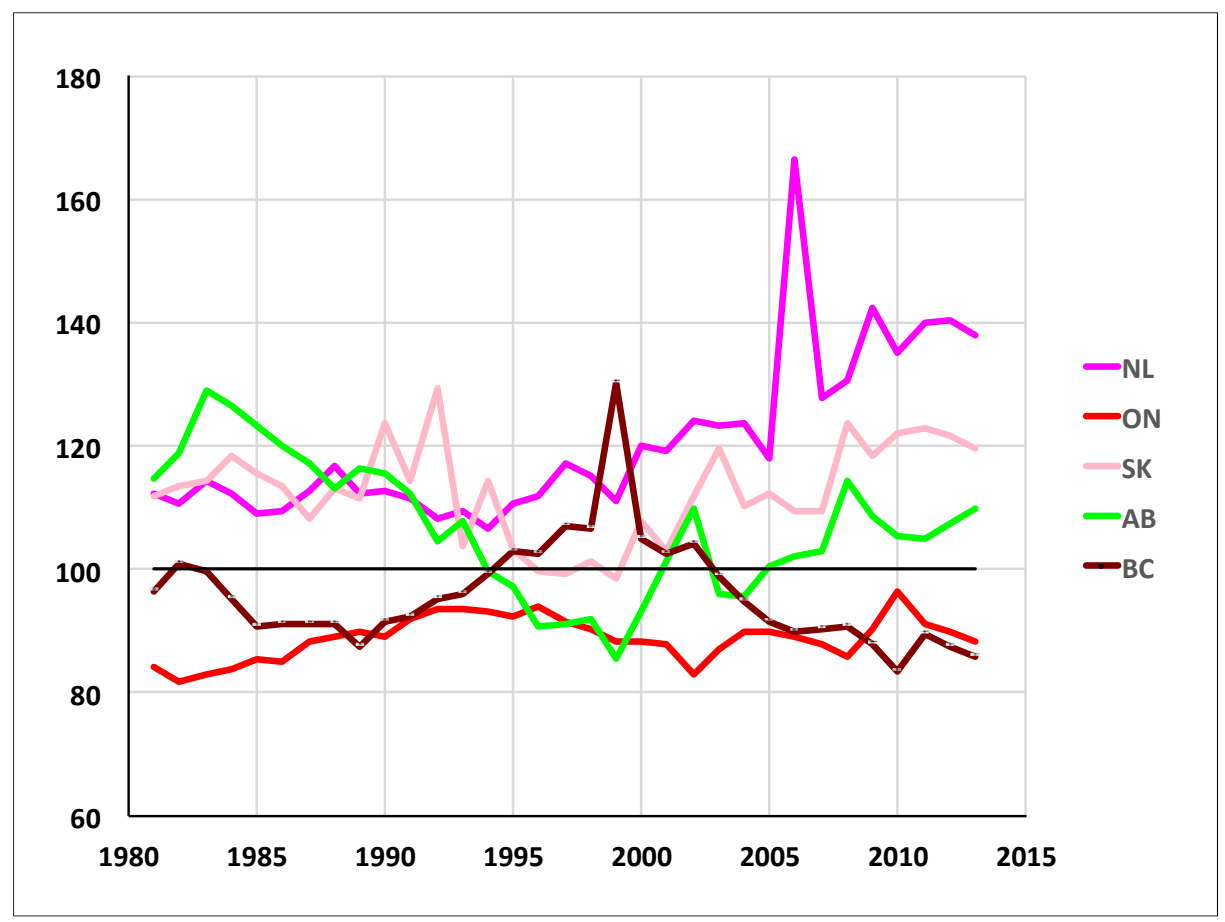

Source: Statistics Canada, 1981-88, Cansim Table 384-0004; 1989-2009, Cansim Table 3850002; 2007-2013, Cansim Table 385-0034; Population Censuses.

(C) Southern Regional Science Association 2016. 


\section{Figure 14: Provincial Government Per Capita Spending, Indexed to the Ten Province Total, (Persistent) Equalization-Recipients, 1980-2013}

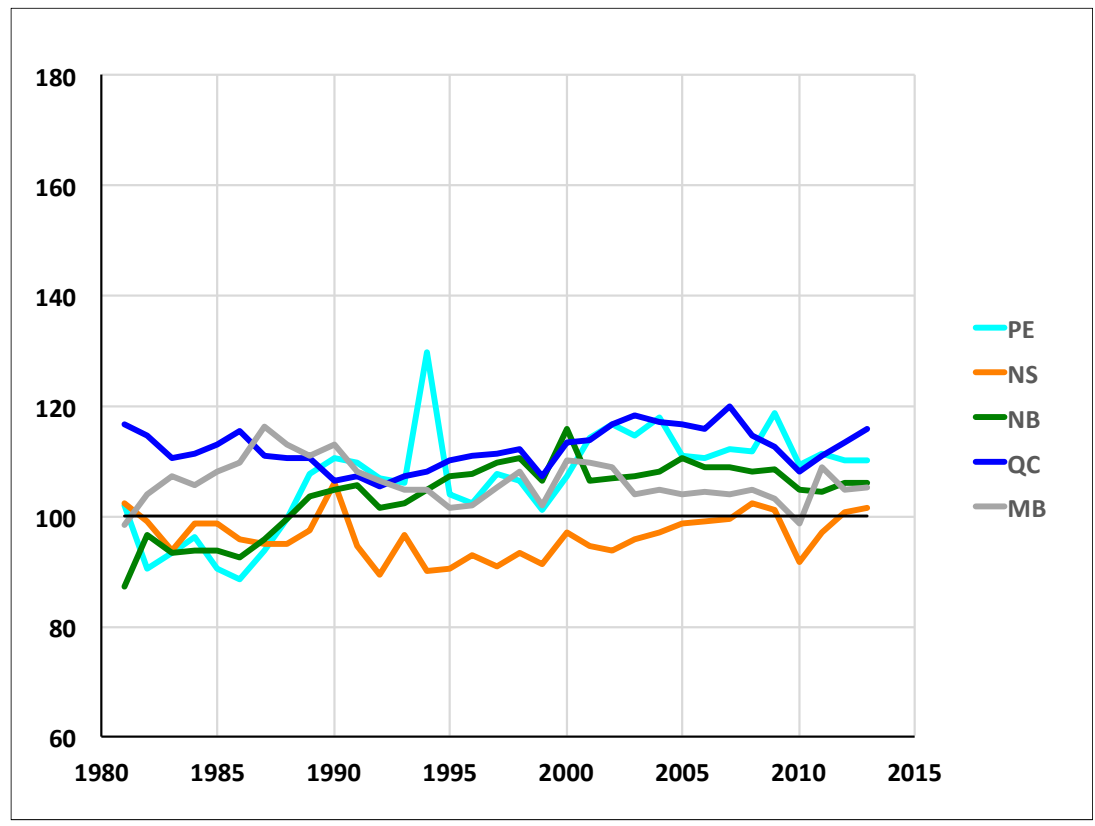

Source: Statistics Canada, 1981-88, Cansim Table 384-0004; 1989-2009, Cansim Table 385-0002; 2007-2013, Cansim Table 385-0034; Population Censuses.

per capita, recognizing that there are other metrics, and influences other than income that affect both migration and government transfers.

Just a quick glance at Figure 15 suggests that there has been convergence for most provinces, taking a fairly long view, from 1926 to 2015. Looking a little more closely, AB (neon green) seems to be on its own trajectory, though I would note that this predates the effects of the 2014 fall in oil prices. Further, QC (in royal blue) seems to have converged until about 1976 and then stopped. Clearly the rate and consistency of convergence has varied considerably across provinces.

\section{CONCLUSIONS}

By way of conclusion, vastly "different" provinces mostly display convergence in per capita disposable incomes over about a 90-year period. Still, even if we concede a convergence pattern, there are explanations that are independent of the roles of interprovincial migration and government policy. All provinces have become more urbanized over this period, with urbanization being an equalizing force. Certainly the metrics for indicating convergence, as well as the potential influences, are complex. The research challenges that emerge are familiar. The factors influencing regional growth trajectories include initial conditions, exogenous changes, migration responses, and government policy. Disentangling these sometimes offsetting effects remains fertile ground for research. It is also important to determine the efficiency costs of equalizing government policies (even assuming they have the desired equalizing effects) and the trade-offs between efficiency and equity. 
Figure 15: Real Household Disposable Income per Capita (2002 Dollars), 1926-2013

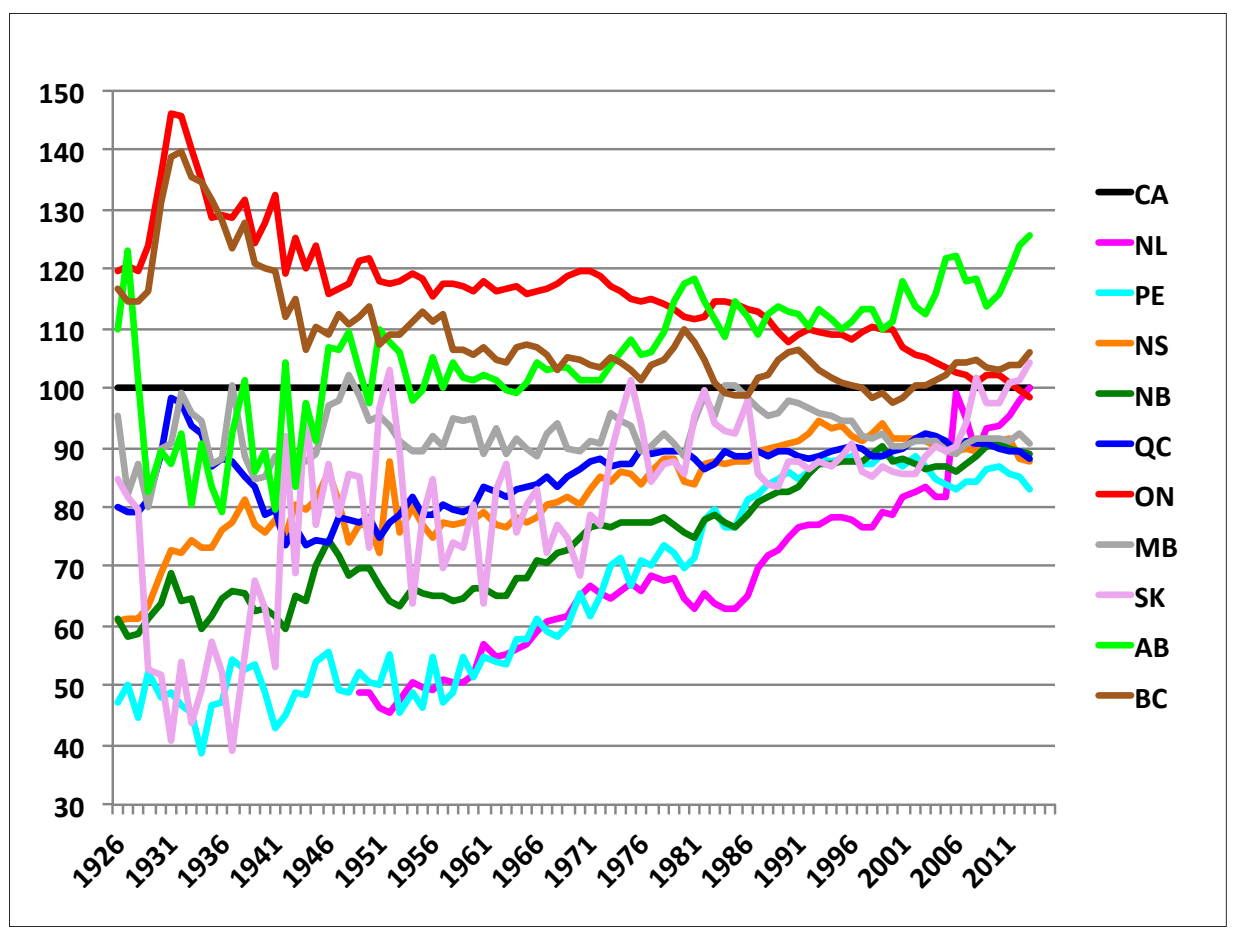

Source: Statistics Canada, Cansim Table 384-5000, Provincial Gross Domestic Product Accounts - 1902 .

\section{REFERENCES}

Arrow, Kenneth J. (1969) "The Organization of Economic Activity: Issues Pertinent to the Choice of Market versus Non-Market Allocation," Analysis and Evaluation of Public Expenditures: The PPB System, 1, 59-73.

Bakhshi, Samira, Mohammad Shakeri, M. Rose Olfert, Mark D. Partridge, and Simon Weseen. (2009) "Do Local Residents Value Federal Transfers? Evidence from Interprovincial Migration in Canada," Public Finance Review, 37, 235-268.

Bergval, Daniel, Claire Charbit, Dirk-Jan Kraan, and Olaf Merk. (2006) "Intergovernmental Transfers and Decentralized Public Spending," OECD Journal on Budgeting, 5, 111-158.

Bird, Richard M. and Almos Tassonyi. (2003) "Constraining Subnational Fiscal Behavior in Canada: Different Approaches, Similar Results?," in Jonathon A. Rodden, Gunnar S. Esckeleand, and Jennie I. Litvack, eds., Fiscal Decentralization and the Challenge of Hard Budget Constraints. MIT Press: Cambridge, MA, pp. 85-133.

Bird, Richard M. and Andrey V. Tarasov. (2004) "Closing the Gap: Fiscal Imbalances and Intergovernmental Transfers in Developed Federations," Environment and Planning C: Government and Policy, 22, 77-102.

Boadway, Robin and Frank Flatters. (1982a) "Efficiency and Equalization Payments in a Federal System of Government: A Synthesis and Extension of Recent Results," Canadian Journal of Economics, 15, 613-633.

(C) Southern Regional Science Association 2016. 
(1982b) Equalization in Federal State: An Economic Analysis. Economic Council of Canada: Ottawa.

Boadway, Robin and Jean-François Tremblay. (2006) "A Theory of Fiscal Imbalance," FinanzArchiv: Public Finance Analysis, 62, 1-27.

Bradford, David F. and Wallace E. Oates. (1971) "Towards a Predictive Theory of Intergovernmental Grants," American Economic Review, 61, 440-448.

Bolton, Roger. (1992) “'Place Prosperity vs People Prosperity’ Revisited: An Old Issue with a New Angle," Urban Studies, 29, 185-203.

Buchanan, James M. (1950) "Federalism and Fiscal Equity," American Economic Review, 40, 583-99.

Bucovetsky, Sam. (1997) "Insurance and Incentive Effects of Transfers among Regions: Equity and Efficiency," International Tax and Public Finance, 4, 463-483.

Constitution Act. (1982) Schedule B to the Canada Act of 1982 (UK), c 11. Last accessed in July 2016 at http://laws-lois.justice.gc.ca/eng/const/page-15.html\#docCont.

Courchene, Thomas J. (1970) “Interprovincial Migration and Economic Adjustment," Canadian Journal of Economics, 3, 550-576.

- (2005) "Resource Revenues and Equalization: Five-province vs. National-average Standards, Alternatives to the Representative Tax System, and Revenue-sharing Pools," Working Paper Number 2005-04, Institute for Research on Public Policy.

Crowley, Brian L. and Bobby O'Keefe. (2006a) "Why Some Provinces are More Equal than Others," Atlantic Institute for Market Studies, Special Equalization Series, Commentary 1.

- (2006b) "The Flypaper Effect," Atlantic Institute for Market Studies, Special Equalization Series, Commentary 2.

Dahlby, Bev. (2002) “The Incentive Effects of Fiscal Equalization Grants," unpublished paper presented at the Atlantic Institute for Market Studies Conference on "Equalization: Welfare Trap or Helping Hand?," Montreal, October 25, 2001.

. (2011) "The Marginal Cost of Public Funds and the Flypaper Effect," International Tax and Public Finance 18, 304-321.

Dahlby, Bev and Ergete Ferede. (2016) "The Stimulative Effects of Intergovernmental Grants and the Marginal Cost of Public Funds," International Tax and Public Finance, 23, 114139.

Day, Kathleen M. (1992) "Interprovincial Migration and Local Public Goods," Canadian Journal of Economics, 25, 123-144.

Day, Kathleen M. and Stanley L. Winer. (2006) "Policy-induced Internal Migration: An Empirical Investigation of the Canadian Case," International Taxation and Public Finance, 13, 535-564.

Ferede, Ergete. (2014) “The Incentive Effects of Equalization Grants on Fiscal Policy," School of Public Policy Research Paper, No. 07.23, University of Calgary.

(c) Southern Regional Science Association 2016. 
Flatters, Frank, J. Vernon Henderson, and Peter M. Mieszkowski. (1974) "Public Goods, Efficiency and Regional Fiscal Equalization,” Journal of Public Economics, 3, 99-112.

Glaeser, Edward L., Jed Kolko and Albert Saiz. (2001) “Consumer City,” Journal of Economic Geography, 1, 27-50.

Gramlich, E. 1977. "Intergovernmental Grants: A Review of the Empirical Literature," in Wallace Oates, ed., The Political Economy of Fiscal Federalism. Lexington Books: Lexington, MA, pp. 219-239.

Groenewold, Nicolaas and Alfred J. Hagger. (2005) "The Effects of an Inter-regional Transfer with Empire-building Regional Governments," Review of Regional Studies, 35, 38-63.

Grossman, Phillip J. (1990) “The Impact of Federal and State Grants on Local Government Spending: A Test of the Fiscal Illusion Hypothesis," Public Finance Review, 18, 313327.

Hall, Jeremy L. (2008) "The Changing Federal Grant Structure and its Potential Effects on State and Local Community Development Efforts," Journal of Public Budgeting, Accounting \& Financial Management, 20, 46-71.

Hamilton, Jonathon H. (1986) "The Flypaper Effect and the Deadweight Loss from Taxation," Journal of Urban Economics, 19, 148-155.

Hamlin, Alan P. (1991) "Decentralization, Competition and the Efficiency of Federalism," Economic Record, 67 193-204.

Hercowitz, Zvi, and David Pines. (1991) “Migration with Fiscal Externalities," Journal of Public Economics, 46, 163-180.

Hines, James R., Jr., and Richard H. Thaler. (1995) "Anomalies: The Flypaper Effect," Journal of Economic Perspectives, 9, 217-226.

Inman, Robert P. (2008) “The Flypaper Effect," Working Paper No. 14579, National Bureau of Economic Research.

Kneebone, Ron. (2012) "How You Pay Determines What You Get: Alternative Financing Options as a Determinant of Publicly Funded Health Care," School of Public Policy Research Paper No. 12.21, University of Calgary.

Library and Archives Canada. (2009) How Canada Was Formed. Last Accessed in July 2016 at https://www.collectionscanada.gc.ca/confederation/kids/023002-1000-e.html.

Logan, Robert R. (1986) "Fiscal Illusion and the Grantor Government," Journal of Political Economy, 94, 1304-1318.

Martinez-Vazquez, Jorge and Jameson Boex. (2001) "The Design of Equalization Grants: Theory and Applications," Andrew Young School of Policy Studies: Georgia State University.

Mieszkowski, Peter and Eric Toder. (1983) "Taxation of Energy Resources," in Charles E. McClure, Jr., and Peter Mieszkowsky, eds., Fiscal Federalism and the Taxation of Natural Resources. Lexington Books: Lexington, MA, pp. 65-91.

Musgrave, Richard A. (1959) The Theory of Public Finance: A Study in Public Finance. McGraw-Hill: New York.

(c) Southern Regional Science Association 2016. 
Myers, Gordon M. (1990) "Optimality, Free Mobility, and the Regional Authority in a Federation," Journal of Public Economics, 43, 107-121.

Oates, Wallace. (1972) Fiscal Federalism. Harcourt Brace Jovanovich: New York.

- (2005) "Toward a Second-generation Theory of Fiscal Federalism," International Tax and Public Finance, 12, 349-373.

- (2006) "The Many Faces of the Tiebout Model," in William A. Fischel, ed., The Tiebout Hypothesis at Fifty: Essays in Public Economics in Honor of Wallace Oates, Lincoln Institute of Land Policy: Cambridge, MA, pp. 21-45.

Partridge, Mark M., Rose Olfert, and Alessandro Alasia. (2007) "Canadian Cities as Engines of Growth: Agglomeration and Amenities," Canadian Journal of Economics, 40, 39-68.

Partridge, Mark D. and Dan S. Rickman. (2008) "Place-Based Policy and Rural Poverty: Insights from the Urban Spatial Mismatch Literature," Cambridge Journal of Regions: Economy and Society, 1, 131-156.

Polèse, Mario and Richard Shearmur. (2006) "Why Some Regions Will Decline: A Canadian Case Study with Thoughts on Local Development Strategies," Papers in Regional Science, 45, 23-46.

Qian, Yingyi and Gerard Roland. (1998) "Federalism and the Soft Budget Constraint," American Economic Review, 88, 1143-1162.

Rosen, Harvey, Jean-Francois Wen, and Tracy Snoddon. (2012) Public Finance in Canada. $4^{\text {th }}$ ed. McGraw-Hill Ryerson: Whitby, ON.

Roy-César, Édison. (2008) “Canada’s Equalization Formula," Publication No. 2008-20-E, Library of Parliament: Ottawa.

Samuelson, Paul A. (1954) "The Pure Theory of Public Expenditure," Review of Economics and Statistics, 36, 387-389.

. (1955) "Diagrammatic Exposition of a Theory of Public Expenditure," Review of Economics and Statistics, 37, 350-356.

Shah, Anwar. (1997) "Fiscal Federalism and Macroeconomic Governance: For Better or for Worse?," Policy Research Working Paper No. 2005, World Bank.

Shaw, R. Paul. (1986) "Fiscal versus Traditional Market Variables in Canadian Migration," Journal of Political Economy, 94, 648-666.

Smart, Michael. (1998) "Taxation and Deadweight Loss in a System of Intergovernmental Transfers," Canadian Journal of Economics, 31, 189-206.

Tiebout, Charles M. (1956) "A Pure Theory of Local Expenditures," Journal of Political Economy, 64, 416-424.

Turnbull, Geoffrey K. (1998) "The Overspending and Flypaper Effects of Fiscal Illusion: Theory and Empirical Evidence," Journal of Urban Economics, 44, 1-26.

(C) Southern Regional Science Association 2016. 
Vaillancourt, Francois and Richard M. Bird. (2005) "Expenditure-based Equalization Transfers," Working Paper 04-10, Andrew Young School of Public Policy, Georgia State University.

Vo, Duc Hong. (2010) "The Economics of Fiscal Decentralization," Journal of Economic Surveys, 24, 657-679.

Wilson, Leonard S. (2003) "Equalization, Efficiency and Migration: Watson Revisited," Canadian Public Policy, 29, 289-308.

Winer, Stanley. (1983) "Some Evidence on the Effect of the Separation of Spending and Taxing Decisions," Journal of Political Economy, 91, 126-140.

Winer, Stanley, and Denis Gauthier. (1982) Internal Migration and Fiscal Structure: An Econometric Study of the Determinants of Interprovincial Migration in Canada. Government of Canada Publications: Ottawa, CA.

Winer, Stanley and Walter Hettich. (2010) "Vertical Imbalance in the Canadian Federation," in Allan M. Maslove, ed., How Ottawa Spends, 2008-2009. McGill-Queen's University Press: Montreal, pp. 59-81. 